\title{
The Relationship between Professional Learning Community and Lesson Study: A Case Study in Low Performing Schools in Sabah, Malaysia
}

\author{
Bitty Ansawi ${ }^{\mathrm{a}}$, Vincent Pang ${ }^{*}$ \\ ${ }^{a}$ Tuaran District Education Office, PO Box 594, 89208 Tuaran, Sabah, Malaysia \\ ${ }^{b}$ Faculty of Psychology and Education, Universiti Malaysia Sabah, Jalan UMS, 88400 Kota Kinabalu, Malaysia
}

*Corresponding author: pvincent@ums.edu.my

\begin{abstract}
Education plays an important role in the development of a nation. Teachers, the main implementer of curriculum at school are subjected to numerous approaches and strategies which have been proven to bring about positive and significant change in students' academic performance. However, the success of these programs depends on the positive perception of these programs. This study aims to identify how lesson study relates to professional learning community practice in the school. A total of 98 teachers selected via purposive sampling from low performing schools in Sabah. Two scales were adapted from past studies to measure the respondents' perception about professional learning community and lesson study practices. Data from the questionnaire was analyzed with IBM SPSS 23.0. Findings showed that teachers perceived both professional learning community and lesson study practices highly. Lesson study and professional learning community showed significant positive and strong relationship. This study implied that teachers in low performing school are receptive of these practices and such attitude may contribute to the success of the SISC+ program in these schools. Findings from this study help policy makers and practitioners to plan strategically on the implementation of these practices in schools.
\end{abstract}

Keywords: Lesson study; SISC+; professional learning community

(C) 2017 Penerbit UTM Press. All rights reserved

\subsection{INTRODUCTION}

Background of the Study

When Vision 2020 was first introduced in 1991, the aspiration to transform Malaysia as a developed nation by year 2020 had led to numerous approaches, policies and programs to ensure that this becomes a reality. Education plays an important tool in the development of a nation. Abiogu (2014) states that education is an important catalyst to ensure meaningful and sustainable growth development and the attainment of success in art, science and technology. Education becomes a core initiator of progress as the Ministry of Education paved the way to create a center of excellence for education within the Asian region and at the global level in this 21 st century. Numerous improvement programs and total quality management were carried out so that Malaysia attains a world class education in the eyes of the world (Ministry of Education, 2006). These changes in the education system are necessary to ensure that Malaysia is able to improve the education quality in the country. Such changes are also inevitable as these are the outcomes from various demands like globalization, computer technology development, internet and multimedia, intense competition and the rising need of knowledge worker or k-workers.

In the Ninth Malaysia Plan (2006-2010), the Government Transformation Program (GTP) was launched as a means of assuring more efficiency in the delivery of public services. Aligned to this effort, the Ministry of Education also implemented GTP1.0 (2010 - 2012) and is implementing GTP 2.0 (2013 - 2025) under the Malaysia Education Development Plan (Ministry of Education, 2012). One of the transformational program introduced by the Ministry of Education is the School Improvement Specialist Coach + (SISC+) which was initiated in 2013 with the intention to reduce the number of low performing schools at band five, six and seven, to zero. Above all, the program aims to improve and enhance the quality of teacher's teaching and learning with guidance from specialist coaches in three subjects: Malay, English and Mathematics (Ministry of Education, 2013). Under this program, there are a number of strategies applied and among them is the implementation of lesson study (Fernandez \& Yoshida, 2004; Lewis, 2002; Lewis \& Hurd, 2011; Stepanek, Appel, Leong, Mangan \& Mitchell, 2007; Mostofo, 2013; Van Sickle, 2011). At the same time, the Ministry of Education has also implemented the professional learning community practices throughout the schools as an effort to encourage lifelong learning and collaboration among professional practitioners (Zuraidah, Rahimah, Muhammad Faizal, \& Hailan, 2012).

Sigurðardóttir (2010) defines professional learning community (PLC) based on the earlier works of Hord (1997), McLaughlin and Talbert (2001), Louis et al. (1996), and Leithwood and Louis (1998) as encompassing a group of professional who shared the same goals and aims, continuously acquiring new knowledge through interaction with one another, with the intention to improve practice. PLC is an imbedded cycle of learning in their daily routine whereby teachers gain new knowledge, try them in practice and from this experience, gain more knowledge. This is done through interaction from one another through collaborative work. In the SISC+, lesson study is one of the many activities carried out to encourage teachers to study the lesson that they had implemented based on observation and reflective discussion 
between the specialist coach and the supervised teachers (Fernandez \& Yoshida, 2004; Isoda, 2007). These practices are new changes that teachers need to adapt to, so that they may improve their instructional skills and bring out better performance among the students.

\section{Problem Statement}

There have been many changes and transformation in the education landscape over the past decades as Malaysia strives to achieve its Vision 2020 , to become a high-income developed nation by the year 2020. Teachers must adapt fast to these changes as they are subjected to new roles and responsibilities. PLC and lesson study are new paradigms in education whereby lesson study is considered as an extension of the activities using promoting PLC. At the same time, the culture of PLC was introduced first before lesson study and the success of lesson study implementation depends on the assimilation and adoption of the PLC culture among the teachers.

A planned change management is not an easy task as the power that influences change and its outcomes are dynamic and complex. Theoretically, the idea is readily accepted but in reality, the practitioners may need to consider many factors that could either encourage or impede the changes. Therefore, the successful implementation of changes in the school depends very much on the readiness and capability of the practitioners, specifically teachers to accept, adapt and implement these changes. Therefore, this study aims to determine the level of teachers' perception about PLC and lesson study practices. Further to that, this study is also interested to know the relationship between PLC and lesson study. The research questions posed in this study are:

(a) What is the level of PLC and lesson study practices as perceived by the supervised English teachers under the SISC+?

(b) Is there any significant relationship between PLC and lesson study?

\subsection{THEORETICAL FOUNDATION OF THE STUDY}

According to the Malaysia Education Plan Annual Report 2013, Malaysia is placed in the last third-bottom of countries in PISA 2012 with more than 50 per cent of students aged 15 years old did not meet the minimum international standard. Results in PISA reinforces the education transformational program through the Malaysian Education Plan (2013-2025) with the aim of putting Malaysian in the first third-top in TIMSS and PISA by year 2025 (Ministry of Education, 2013). In line with school-based management concept, the District Education Department and school were empowered to make their own decisions about the administration and management of their offices. At the district level, specialist coaches were employed on a full-time basis to provide supervision and mentoring to teachers in low performing schools in three subjects: Malay, English and Mathematics. Basically, the main tasks of SISC+ are: to build rapport with teachers and supervise them in school; collaborate with the Ministry and the District Education Officer to provide much needed training for the teachers; design and administer specific intervention to improve instructions in school; and to supervise a number of teachers (minimum 20 and maximum 30 teachers) for a month.

Hence, under SISC+, the teachers participate in specific programs like the lesson study. Through this program, the teachers gain more knowledge and skills through collaboratively measures. This in turn may contribute to the development of PLC. There are some theories that explain about PLC and lesson study.

\section{The Organizational Learning}

Edmonson and Moingeon (1996) stated that an organization in a situation that is ambiguous, changing or uncertain need to learn. This describes the situation faced by educational institutions including schools which are dealing with challenging and dynamic environment where changes are inevitable. In this case, the learning organization concept is a relevant theory to explain the paradigm shift of the education landscape. The learning organization theory was introduced by Senge (1990) in his book, The Fifth Discipline: The Art and Practice of the Learning Organization. The theory provides a comprehensible framework for a group in their effort to learn, develop and change together. DuFour (2004) enriches the idea as a model for professional development. He stated that the teacher professional development need to become an integral part of the teachers' job and not a particular focus or a different entity. According to DuFour's model on professional learning community, school leaders need to deal tangently with teachers' development, encourage actions like teacher collaboration, dialogue and reflection through an organizational structure and expectation, and not merely a formal and scheduled professional development experience (Parry, 2007). The five disciplines of organizational learning first introduced by Senge (1990): personal mastery, mental modal, mutual vision, team learning and systemic thinking are similar to the basic characteristics of the professional learning community suggested by DuFour and Eaker (1998): mutual mission, vision and values, collective inquiry and action-oriented, collaborative team, commitment towards continuous improvement and result-oriented.

The organizational learning concept is defined as a scheme of information management that comprises of systematic efforts to transfer knowledge to the entire organization (Arumugam, Khairuddin \& Munusamy, 2015; Spector \& Davidsen, 2006). Learning is about how members of the organization are involved in the process of creating to transfer or improve their skills and current routines as well as how they question the reason to use diagnostic skills (Edmonsen \& Moingeon, 1996). Learning requires change in their ability, attitude, belief, capabilities, knowledge, mental mode, skills and such that occur at a certain period of time (Spector \& Davidsen, 2006). Learning may not always be effective to attain the desired outcome continuously either intentionally or not. Therefore, a learning organization refers to an organization that can create a clear goal, monitor the development of these goals and make appropriate consideration about the dynamic situation that is always developing (Arumugam et al., 2015; Spector \& Davidsen, 2006). Hence, professional learning community serves as a theoretical foundation to understand practices that are incorporated in this practice.

\section{Constructivist Learning Theory}

Another theory that provides the theoretical foundation to explain professional learning community and lesson plan is the constructivist theory. Constructivism is an epistemology or a theory that is used to explain how people know what they know. Basically, the theory states that an individual build his understanding and knowledge about the world through experience and reflection of the experience (Bhatacharjee, 
2015). Professional learning community and lesson study focuses on immersing in experience and particularly in lesson study, reflection is necessary to understand how instruction in the classroom can be further improved.

Piaget introduced the theory of constructivism by explaining the mechanism of how students acquire knowledge. He proposed the accommodation and assimilation processes whereby individual create new knowledge based on their experience. When the individual assimilates, he is adding new experience to the existing framework without changing the framework. This occurs when the individual's experience is aligned to the internal representation about the world but there might be incidents when failure to understand happens. When an individual's experience differs from the internal representation, he needs to change the perception of his experience to match the internal representation. According to this theory, accommodation is a process to reframe the mental representation about the outside world to match the new experience. Accommodation is a mechanism whereby failure brings learning: when a person act towards an expectation that the world operates in a certain way but did not match the expectation, then he had failed but by accommodating the new experience, and reframing the model of how the world works, he learned from the failed experience or from others' failure. This spells out the cognitive and emotive process that are encompassed within the framework of professional learning community and lesson study. Constructivism supports the act of reflecting upon experience and the creation of self-meaning about the world (Bhattacharjee, 2015).

The professional learning community concept is supported by the constructivist theory to explain the learning process. It means that professional learning among the teachers and students' learning are not consistent but a dynamic and ongoing process whereby feedbacks, social interaction and active participation play important roles. According to Murphy (1997), the constructivist perspective explains knowledge as something that is build actively by the individual through interaction with the surrounding in his effort to understand life. Hord (2009) explains further that learning constructively needs an environment whereby the learner works collegially and situated in the activity and in genuine context. Bhattacharjee (2015) stated that there are some principles that serve as guidelines for constructivist learning. Firstly, learning is a quest for meaning. Therefore, it begins with an issue that is actively given a meaning. Secondly, the meaning needs an understanding of the overall and its parts. The parts need to be understood in the overall context. Therefore, the process of learning gives focus on basic concepts and not on isolated facts. Thirdly, to teach properly, the individual need to understand the mental mode used by the students to understand the world and the assumptions they made to support this model. Lastly, the goal of learning is to ensure that the individual make their own meaning, not from memorizing the correct answer or repeating the meaning given by someone else.

These explanation shows that lesson study is a process of making meaning by the individual teacher based on their own experience and a reflection of these experiences. The making of experience is the outcome from activities that are carried out to enhance their skills. Good and Brophy (1994) explained that constructive learning needs the learners to build their own meaning actively. They need to own the knowledge so that they can manipulate, discover and create knowledge that suited their belief system. They make effort to understand new information by relating them with old knowledge. They compare and question, challenge and investigate, accept and reject old information and assumptions to show signs on development. These explain the activities that are carried out in lesson study practice.

\section{The Socio-Cultural Learning Theory}

Another theory that is closely related to professional learning community is the socio-cultural learning theory whereby in tis theory, learners are defined as an active knowledge creator with their own knowledge structure based on social interaction. Wells (2001) explained that knowledge is built and rebuilt among learners in a specific situation, using the same cultural resources that they have, while working together towards a collaborative goal that is the result of their actions together. The making of this knowledge happens among the leaners who are involved to find meanings together with others to extend and change their collective understanding about some aspects in the activities that they do together. Though this enculturation process, the learners develop their own understanding about the information and transfer them to current practice. Thus, the organizational structure in the professional learning community support the making of knowledge via social participation. The premise of the professional community is dependent on the acquisition of knowledge via social interaction and professional dialogues.

\subsection{CONCEPTUAL FRAMEWORK}

\section{Professional Learning Community}

The teacher is the curriculum implementer in the school. Therefore, their knowledge, skills and competence to carry out the teaching and learning process is critical to ensure excellence in students' performance. Teachers become the main target to increase the instructional quality based on retraining and enhancement of their instructional skills via the professional learning community and a more contextual teacher professionalism (Ministry of Education, 2013). Thus, professional learning community becomes a strategy that is hoped to increase the teachers' knowledge, skills and competence continuously. The creation and development of successful schools is an aspiration that is constantly sought in the education world. In fact, many researchers attempt to find an accurate formula to create such a school. Hord (1997) was involved in a study under the Southwest Educational Development Laboratory (SEDL) and found that successful schools have the same characteristics of the learning organization introduced by Senge (1990). Their study then proposed a new model for school improvement that is the professional learning community.

The professional learning community is defined as a group of people who share and critically analyze their practices in an ongoing, reflective, collaborative, inclusive and learning-oriented manner and encouraging growth (Stoll, Bolam, McMohan, Wallace \& Thomas, 2006). Hence, PLC can be pictured as a community that practices the learning culture in the school. The promotion of a learning culture among the members within the school community contributes to the improvement in the teaching and learning methods, management and school leadership (Hipp \& Huffman, 2003; Abdullah \& Ghani, 2014). Everyone in the community plays his roles and is responsible for each other to learn so that the well-being of everyone is maintained (Myers \& Simpson, 1998). DuFour et al. (2006) stated that a highly committed teacher who perform his duties collaboratively especially in inquiry collective activities and action research can lead to better outcomes. The collaborative factor refers to the shared viewpoints and experience which provide opportunity for learning to the teachers (McLaughlin \& Talbert, 2006). Comprehensively, some researchers like Hord (1997), McLaughlin and Talbert (2001), Louis et al. (1996) and Leithwood 
and Louis (1998) gave the definition of PLC as encompassing a professional group that share goals and purpose, continue to acquire new knowledge via interaction with each other, and aiming for improvement in practice. It is a cycle where learning is normally imbedded in daily work routine, that the teacher is able to acquire them, try them in their practice, and from then on gain experience and later on, more knowledge. These are accomplished as they interact with one another through collaborative work. The cycle is highly influenced by structural factors that either promote or hinder collaboration; cultural factors that are associated with a person's belief and values; and the leadership styles that influence the culture and structure in the school.

PLC is a concept that arises from the research and theories in the education field. The concept is very much related to the organizational learning concept of Senge (1990). The education institutions like school need to become a learning organization to increase the capacity among the education community (DuFour et al., 2008; Marshall, 2007). This is because the scenario of education is complex, constantly changing and difficult to predict the future (Hord, 1997). Therefore, in organizational learning, the focus is on the community's collaborative effort rather than on individual effort to develop the organization's capacity. In Malaysia, PLC refers to a group of six to twelve teachers who are constantly in contact with each other and conduct discussion about their teaching. The meeting is frequent with reflective dialogues about students' learning based on a protocol that encourages critique acceptance without intending to be personal but for the improvement of the students (Yendol, 2010). The basic thing given attention is the quality of teaching and learning in the classroom. In this sense, lesson study becomes a good forum for the teachers to discuss and reflect on quality instructions in the classroom, effective questioning method, good classroom management and discussion on the difficulty of students to accept what is being taught (Ministry of Education, 2011).

Hord (2004) explains that there are five dimensions in PLC: supportive and shared leadership, shared values and focused vision on students' learning, collective learning, supporting conditions and shared personal practices. Louis, Marks and Kruse (1996) added another dimension, reflective dialogues. Supportive and shared leadership accentuates the role of the leader who need to be an advocator for collaborative action and support the development of PLC. Within the PLC framework, the members of the school community which include the principal, the administrators, the teachers, students and parents work to attain shared goals (Morrissey, 2000). Shared values and vision imply that each member of the professional community is in consensus about the values and vision that they uphold as characteristics of their professional behaviors (Roberts \& Pruitt, 2009). On the other hand, collective learning and application focuses on the growth and development of all the students. The professionals participate in dialogues and make decisions about curriculum, teaching and learning that lead to students' success (Lokman, Mohd Nira, Mohd Fazli, Narina, Khadijah, \& Tasia, 2013). Shared personal practice means that there is a strong regard for high levels of achievement within an environment that promotes continuous inquiry and improvement. PLC prompts all members of the community to achieve a high standard. Therefore, there is a shared purpose of improving the learning outcomes of the students. Ideas are shared among members of the community so that they may learn from each other, and help them to attain personal best (Roberts \& Pruitt, 2009). Lastly, supportive conditions identify when, where and how the community members come together to learn, make decision and do creative works. There are two types of support: structural condition and collegial relationships. Structural condition refers to the utilization of time, communication process, size of the organization, proximity of the professional and staff development processes. Collegial relationships are about positive attitudes of the professionals, widely share vision, norms of continuous critical inquiry and improvement, respect, trust, positive and caring relationships (Lokman et al., 2013).

DuFour (2004) states that there are three main ideas underlying the PLC concept. The first idea states the need to ensure that students learn. This suggests that students not only have the rights to attend teachers' teaching but they are also entitled to learn. Therefore, there is a shift from teaching to learning (Fullan, 2002). The second idea stresses on the collaborative culture which is not promoted by some schools (Boyd \& Hord, 2012). Teachers often work in isolation. Although the school has several committees and panels to represent some aspects of the school development, often there is no professional dialogue among them. It is imperative that schools work as a team to analyze and improve classroom practices (McLaughlin \& Talbert, 2001).

Lastly, there should be a focus on the outcomes. Schools of today seem to be "rich in data but lacking information" [29] as teachers are instructed to feed information into the system but these data are not transformed into useful information that could be utilized for students' improvement. Therefore, collaborative efforts where teachers combine all aspect with their colleagues such as ideas, teaching aids, strategies and talent should be done to enhance students' performance (Barth, 1991; Marzano, 2003).

\section{Lesson Study}

Lesson study is a collaborative teaching and learning activity that is gaining popularity in education system of developed countries. Lesson study is a strategy that was initiated since 2011 by Teacher Education Division in 289 low performing schools. It is a teacher professional development model that was practiced in Japan more than a decade ago (Isoda, 2007). The model was popularly used in the 1960s and became a cultural practice among elementary school teachers in Japan (Fernandez \& Yoshida, 2004). The effectiveness of lesson study in Japan to improve students' learning had led to the adoption of this strategy in schools in the United Stated (Lewis, Perry \& Murata, 2006). Now, it is acknowledged as a key factor of improving students learning (Fernandez \& Yoshida, 2004; Lewis, 2002; Stigler \& Herbert, 1999).

In the Japanese language, lesson study is known as "jugyoukenkyuu" whereby "jugyou" means "lesson" or "teaching while "kenkyuu" means study or investigation. Thus, lesson study means a study or investigation that involves observation on teachers' teaching in the classroom (Fernandez, 2005). Lesson study in general, is a systematic inquiry approach towards instructional practice and it is collaborative in nature (Fernandez \& Yoshida, 2004; Isoda, 2007; Lee, 2008, Lewis, 2009). Its successful implementation needs teachers to accept it as a research process by asking in-depth question, designing the experiment that would answer the questions, collect evidence and interpret then as well as generalizing the findings (Fernandez, 2005). The participation of an advisor or coach from outside the school also showed a better outcome (Chokshi \& Fernandez, 2004). This explains why SISC+ included lesson study as part of their strategies to help teachers improve their instructional qualities in low performing schools.

Lesson study is based on a bottom-up model whereby its implementation is based on the initiatives of the teachers and not according to directives from their superiors. By practicing lesson study, the teachers hold on to the concept of lifelong learning. Hiebert et al. (2002) explained that lesson study can help teachers to share, discuss, debate and confirm that a teaching process is truly effective especially in today's situation whereby teachers face a bigger challenge to achieve a particular standard. The collaborative practice in lesson study requires mobilization of ideas, experiences and skills that contribute to improvement in content knowledge and pedagogical knowledge of the teacher. The process in lesson study requires the teachers to meet and discuss so that they can enhance growth of knowledge, idea development and 
creativity of the individuals to develop them prepare their daily teaching plan together. Such practice encourages oneness and ownership among the teachers. The relevance of lesson study is linked to the belief that people learn in a community (Hiebert, Gallimore \& Stigler, 2002) and the teacher learning community is collaborative and collegial for professional development (Chokshi \& Fernandez, 2004; Fernandez \& Yoshida, 2004; Lewis, 2009).

\subsection{METHODOLOGY}

\section{Research Design}

The research design is a overall plan that the researcher used to determine the real framework of the study to give specific information about the process that are undertaken in implementing the research (Robson, 2002). This study is a survey-based research whereby it is dependent on the measurement of changes that happened after the implementation of an intervention and then a sample group is selected to represent the population affected by the change (Bethlehem, 1999; Bourque, 2004; Hall, 2008). This explains the focus of the study on determining PLC and lesson study practices among the supervised English teachers by SISC+. The research design uses a passive approach by making inference on the cause and effect based on research findings. This cross-sectional study provides a clear snapshot of the outcomes (Hall, 2008) and explains the level of professional learning community and lesson study practices, as well as explanatory in nature to explain the relationships between the variables (Zikmund, Babin, Carr \& Griffin, 2012). To explain the phenomena, a quantitative approach based on empirical data collected via survey with questionnaire distribution to teachers in low performing schools in Sabah. Creswell (2008) explains that a quantitative approach uses a post-positivist paradigm to explain the studied phenomena.

\section{Population and Sampling Method}

The definition of the study population is important to build the sampling plan. According to Sekaran and Bougie (2010), population refers to a group of people, events or things that are of interest to the researcher. Population is also described as any set of people or subject wiith similar observed characteristics (Kumar, Abdul Talib \& Ramayah, 2013). In this study, the population is identified as English teachers in low performing schools (identified as Band 4 to Band 7 by the Sabah Education Department Statistics in 2015) in Sabah supervised by their respective SISC + . At the time of this discussion, the statistics recorded 39 low performing schools and at an average of $2-4$ teachers in each school. The population size is approximately 120 teachers. Purposive sampling was used to select respondent with a sample size of 98 . Respondents were selected based on an inclusion criteria: (i) the teacher has been under the supervision of the SISC+ for at least six months; (ii) the teacher is involved in both PLC and lesson study practices; (iii) the teacher is teaching in a low performing school.

Krejcie and Morgan (1970) explained that the sample size of 98 is adequate to support the generalization of the findings to the identified population. The determination of the sample size is also consistent with sample size requirement proposed by Akter, D'Ambra and Ray (2011) which explains the critical role of power analysis to determine adequate sample size. In general, power is defined as the probability of obtaining a statistically significant result that is rejecting the null hypothesis (Cohen, 1988). The G*Power 3.1.2 software was used to determine the sample size for this study (Faul et al., 2009). In general, the statistical test power must be at least 0.80 (Cohen, 1988). A higher power (more than 0.80) shows that there is a greater probability to produce a significant result when the relationship is truly significant. In this study, the use of G*Power 3.1.2 (Faul et al., 2009) was based on a few requirements such as two predictors (six professional learning community and lesson study), 0.80 power, significant level 0.05 , and effect size of 0.15 . based on the G Power analysis, the adequate sample size is 68. Therefore, adopting a larger sample size at 98 provides less estimation error (Cooper \& Schindler, 2008) and gives a more accurate finding.

These samples consisted of $25(25.5 \%)$ males and $73(74.5 \%)$ females. The teachers are mostly $(75$ teachers, $76.5 \%)$ between the age of 30 and 45 years old, followed by 13 teachers (13.3\%) aged between 46 and 55 years, while eight teachers (8.2\%) were less than 30 years old and two of them $(2.0 \%)$ were more than 55 years old. Majority (52 teachers, $53.1 \%$ ) of the teachers have worked for more than ten years. There were 21 teachers $(21.4 \%)$ who have worked from six to ten years while 12 teachers $(12.2 \%)$ worked between three and five years and 13 of the teachers (13.3\%) worked less than three years.

\section{Research Instrument \& Data Analysis}

The PLC part of the questionnaire was adopted from Zuraidah et al. [42]. There are 62 items representing six dimensions: shared values and mutual vision, supporting condition (human relationship), supporting condition (school structure), shared and supportive leadership, collective learning and application, and shared personal practices. Another part to measure lesson study application was developed from past studies [40, 41, 43, 44] with 15 items which is divided into three dimensions: collaborative planning, debriefing session and lesson revision. Reliability test of the scale showed that the professional learning community scale has a Cronbach's Alpha value of 0.977 whereas for lesson study scale, Cronbach's Alpha is 0.961 . George and Mallery (2003) stated that a value above 0.90 indicates excellent internal consistency. Data from the questionnaire was analyzed with IBM SPSS Statistics 23.0 using descriptive and inferential statistical analyses

\subsection{RESULTS AND DISCUSSION}

\section{Professional Learning Practices}

Table 1 shows the descriptive analysis results that indicate the level of perception on PLC. All dimensions as well as overall PLC were perceived highly except for School Structure which is perceived moderately. Based on the mean values, it is shown that shared values and mutual vision was perceived the highest (mean $=3.9613$ ) followed by supporting condition (human relationship) with mean value of 3.9482 . 
This was followed by collective learning and its application (mean $=3.9183$ ). The lowest perceived dimension is supporting condition (school structure) with a mean score of 3.6465. Overall, the perception on PLC practices was high $($ mean $=3.8624)$.

Table 1 Level of perception on professional learning community practices.

\begin{tabular}{lcc}
\hline \multicolumn{1}{c}{ Constructs/Dimension } & Mean & Level \\
\hline Shared Values and Mutual Vision & 3.9613 & High \\
Supporting Condition (Human Relations) & 3.9482 & High \\
Supporting Condition (School Structure) & 3.6465 & Moderate \\
Shared and Supportive Leadership & 3.7594 & High \\
Collective Learning and its Application & 3.9183 & High \\
Shared Personal Practices & 3.7466 & High \\
\hline Overall PLC & 3.8264 & High \\
\hline
\end{tabular}

Compared with findings from Zuraidah et al. (2012), the practices of the teachers are almost similar to that of secondary schools in West Malaysia. In their study, shared values, goals, mission and vision were ranked the highest. The same is indicated in this current study. This suggests that teachers and their SISC+ shared a vision that focuses on the learning of the students and there is a collective effort to bring improvement to this (Rechstetter, 2006). Supporting condition (human relations) was ranked second. This implies that collaboration among the teachers is high and there is a collective effort from all PLC members to implement it successfully. This dimension portrays the presence of collaborative relationship in the school community which is focused on enhancing the process of information delivery process and decision making based on knowledge. Such collaborative work practices will produce effective curriculum and teaching practices (Zuraidah et al., 2012). In this study, collective learning and its application was ranked third highest. This suggests that the teachers collaborate to improve the effectiveness of information delivery and decision making in teaching English. Nevertheless, supporting condition in terms of school structure was perceived moderately. 'Structures' refers to the use of time, communication procedures, size of the institution, proximity of academic staff, and staff development processes (Hord, 1997). It implies the need to further improve existing structure particularly in terms of communication.

\section{Lesson Study Practices}

Table 2 shows the perception level on lesson study, indicating high mean scores for each of the dimensions and overall lesson study. Collaborative planning was perceived the highest $($ mean $=4.1816)$ followed by debriefing session $($ mean $=4.1347)$ and lastly, lesson revision $($ mean $=4.1306)$. Overall, the perception of the lesson study was high $($ mean $=4.1460)$. The high perception on each dimension of lesson study showed that teachers welcome this practice. Most often, teachers work in isolation. There maybe some committees and panels that exist in the school to assist in planning their daily teaching plan, but most often, teachers impl ement them individually. With lesson study practices, there is more professional dialogue among the teachers (McLaughlin \& Talbert, 2001).

Table 2 Level of perception on lesson study.

\begin{tabular}{lcc}
\hline \multicolumn{1}{c}{ Constructs/Dimension } & Mean & Level \\
\hline Collaborative Planning & 4.1816 & High \\
Debriefing Session & 4.1347 & High \\
Lesson Revision & 4.1306 & High \\
\hline Overall & 4.1460 & High \\
\hline
\end{tabular}

Relationship between PLC practices and Lesson Study

Table 3 shows the result of the Pearson correlation analysis at 95\% confidence level. It shows that PLC has a significant, po sitive and strong correlation with lesson study $(\mathrm{r}=0.732, \mathrm{p}=0.000)$. The result showed that a positive perception on PLC helps to develop acceptance of lesson study and greater willingness to implement this practice. It connects PLC as a concept that is practiced widely in the teachers' routine daily job to a specific practical activity like lesson study. In other words, the implementation of contextual practice in the form of lesson study is strengthened when the teachers have embraced the concept of PLC itself.

Table 3 Correlation between PLC and lesson study

\begin{tabular}{cccc}
\hline $\begin{array}{c}\text { Correlation of PLC } \\
\text { with }\end{array}$ & N & Pearson Correlation & Sig. (2-tailed) \\
\hline Lesson Study & 98 & $0.732^{* *}$ & 0.000 \\
\hline$* *$ Correlation is significant at the 0.01 level (2-tailed) & &
\end{tabular}

\subsection{CONCLUSION}

The study showed that teachers perceived PLC practices and lesson study positively, thus indicating that these changes are well accepted by the teachers. However, the moderate level of perception for school structure implied the need to ensure more efforts to provide better facilities and resources to enable teacher to carry out teaching and learning more effectively in the classroom. Their high perception on lesson study implied collaborative and reflective practices among teachers are very much in the daily practices. Hence, it is crucial that schools provide 
more opportunities for teachers to discuss and collaborate to ensure greater improvement in teaching and learning delivery. The positive high correlation between PLC and lesson study implies that lesson studies implemented in schools may influence PLC practices. This study also highlighted the necessity of assessing other implemented strategies such as peer coaching under the SISC + to see whether those programs are also accepted positively by teachers in low performing schools.

\section{References}

Abdullah, Z. and Ghani, M. F. A. (2013). Professional Learning Community: A Guideline to Improve Education System in Malaysia, Hope Journal of Research, 1(4), $1-26$.

Abdullah. Z. and Ghani, M.F.A (2014). Professional Learning Community in Secondary Schools Community in Malaysia. Journal of Education and Learning, 8(3), 227-248.

Abiogu, G. (2014). Philosophy of Education: A Tool for National Development? Open Journal of Philosophy, 4(3), 372-377.

Akter, S., D'Ambra, J. \& Ray, P. (2011). Trustworthiness in Health Information Services: An Assessment of a Hierarchical Model with Mediating and Moderating Effects Using Partial Least Squares (PLS). Journal of the American Society for Information Science and Technology, 62(1), 100-116.

Andrews, D. and Lewis, M. (2007). Transforming Practice from Within: The Power Of The Professional Learning Community. In L. Stoll \& K. S. Louis (Eds.), Professional learning communities: Divergence, Depth and Dilemmas (132-147). New York, NY: Open University Press.

Arumugam, T., Khairuddin, I. \& Munusamy, K. (2015). Conceptualizing Organizational Learning System Model and Innovativeness. International Journal of Business and Social Science, 6(3), 155-165

Barth, R. (1991). Restructuring Schools: Some Questions for Teachers and Principals. Phi Kappan, 73(2), 123-128.

Bhattacharje, J. (2015). Constructivist Approach to Learning - An Effective Approach of Teaching Learning. International Research Journal of Interdisciplinary \& Multidisciplinary Studies, I(VI), 65-74.

Bethlehem, J. (1999). Cross-Sectional Research. In Research Methodology in the Social, Behavioural and Life Sciences. Adèr, H. J. \& Mellenbergh, G. J. (editor) London, England: Sage.

Bourque, L B. (2004). Cross-Sectional Design. In The SAGE Encyclopedia of Social Science Research Methods. Lewis-Beck, M. S., Bryman, A. \& Liao, T. F. Thousand Oaks, CA.

Boyd, V., and Hord, S. M. (2012). Schools as Learning Communities. Issues about Change, 4(1), 1- 8.

Chokshi, S., \& Fernandez, C. (2004). Challenges to Importing Japanese Lesson Study: Concerns, Misconceptions, and Nuances. Phi Delta Kappan, 85(7), 520-525.

Cohen, J. (1988). Statistical Power Analysis for the Behavioral Sciences (2nd ed.). Hillsdale, NJ: Lawrence Earlbaum Associates.

Cooper, C. R., \& Schindler, P. S. (2008). Business Research Methods (10 ed.). Boston: McGraw-Hill.

Creswell, J. W.( 2008). Educational Research: Planning, Conducting and Evaluation Quantitative and Qualitative Research (3rd ed.). Upper Saddle River, NJ: Pearson Education.

Donaldson, D. P. (2006). Sustaining Change in Schools: How to Overcome Differences and Focus on Quality. Alexandria, VA: Association for Supervision and Curriculum Development.

DuFour, R. (2004). What is a Professional Learning Community? Educational Leadership, 61(8), 6-11.

DuFour, R. and Eaker, R. (1998). Professional Learning Communities at Work: Best Practices for Enhancing Student Achievement. Alexandria, VA: Association for Supervision and Curriculum Development.

DuFour, R., DuFour, R., Eaker, R., \& Many, T. (2006). Learning by Doing: A Handbook for Professional Learning Communities that Work. Bloomington, IN: Solution Tree Press.

DuFour, R., DuFour, R., \& Eaker, R. (2008). Revisiting Professional Learning Communities at Work: New Insights for Improving Schools. Bloomington, IN: Solution Tree Press.

Edmondson A. \& Moingeon, B. (1996). When to Learn How and When to Learn Why. Appropriate Organizational Learning Processes as a Source Of Competitive Advantage. In Moingeon, B. dan Edmondson, A. (eds). Organizational Learning and Competitive Advantage, London: Sage.

Faul, F., Erdfelder, E., Lang, A. G. \& Buchner, A. (2007). G* Power 3: a Flexible Statistical Power Analysis Program for the Social, Behavioral, and Biomedical Sciences. Behavior Research Methods, 39, 175-191.

Fernandez, M. L. (2005). Exploring "Lesson Study" in Teacher Preparation. in Chick, H. L. \& Vincent, J. L. (eds), Proceedings of the 29th Conference of the International Group for the Psychology of Mathematics Education, 2, 305-312.

Fernandez, C., and Yoshida, M. (2004). Lesson study: A Japanese approach to improving mathematics teaching and learning. Mahwah, New Jersey Lawrence Erlbaum Associates.

Fullan, M. (2002). Principals as Leaders in a Culture of Change. Paper prepared for Educational Leadership.

George, D. \& Mallery, P. (2003). SPSS For Window Step By Step: A Simple Guide and Reference 11.0 Update. 4th Ed. United States of America: Pearson Education Inc.

Good, T.L. \& Brophy, J.E. (1994). Looking in Classrooms., New York, NY: HarperCollins College Publishers.

Hall, J. (2008). Cross-Sectional Survey Design. In Encyclopedia of Survey Research Methods. Paul J. Lavrakas, ed. Thousand Oaks, CA: Sage.

Harris, A. and Jones. M. (2010). Professional Learning Communities and System Improvement. Improving Schools, 13(2), 172-181.

Herrington, R. (2011). Professional Learning Communities: Perceptions of Teacher Quality and Sustainability. Walden University, Walden.

Hiebert, J., Gallimore, R., \& Stigler, R. W. (2002). A Knowledge Base for The Teaching Profession: What Would It Look Like and How Can We Get One? Educational Researcher, 31(5), 3-15.

Hipp, K. A. and Huffinan, J. B. (2003). Professional Learning Communities: Assessment-Development Effects. Paper presented at the Annual Conference of the International Congress for School Effectiveness and Improvement. Sydney, Australia.

Hord, S.M. (1997). Professional Learning Communities: Communities of Continuous Inquiry and Improvement. Austin, Texas: Southwest Educational Development Laboratory.

Hord, S. (2004). Professional Learning Communities: An Overview. In S. Hord (ed), Learning Together, Leading Together: Changing Schools Through Professional Learning Communities. New York: Teachers College Press

Hord, S. M. (2009). Professional Learning Communities: Educators Work Together Toward a Shared Purpose - Improved Student Learning. Journal of Staff Development, $30(1), 40-44$

Isoda, M. (2007). Where did Lesson Study Begin, and How Far Has It Come? In Isoda, M., Stephens, M., Ohara, Y. \& Miyakawa, T. edited (2007). Japanese Lesson Study in Mathematics, Singapore: World Scientific. 5-11.

Krejcie, R.V. \& Morgan, D.W. (1970). Determining Sample Size for Research Activities. Educational and Psychological Measurement. 30(3): 607-610.

Kumar, M., Talib, S.A., \& Ramayah, T. (2013). Business Research Methods. Kuala Lumpur: Oxford University Press.

Leithwood, K., \& Louis, K.S. (Eds.). (1998). Organizational Learning in Schools. Lisse. The Netherlands: Swetz \& Zeitlinger.

Lee, J. F. K. (2008). A Hong Kong Case of Lesson Study - Benefits and Concerns. Teaching and Teacher Education, 24(5), 1115-1124.

Lewis, C. (2002). Lesson Study: A Handbook for Teacher-Led Instructional Change. Philadelphia: Research for Better Schools, Inc.

Lewis, C. (2009). What is the Nature of Knowledge Development in Lesson Study? Educational Action Research, 17(1), 95-110.

Lewis, C., and Hurd, J. (2011). Lesson Study Step By Step: How Teacher Learning Communities Improve Instruction. Portsmouth, NH: Heinneman.

Lewis, C., Perry, R., and Murata, A. (2006). How Should Research Contribute to Instructional Improvement: The Case of Lesson Study. Educational Researcher, 35(3), 3-14. 
Lokman, M. T., Mohd, Nira, H. M. S., Mohd Fazli, A., Narina, A. S., Khadijah, D. and Tasia, H. M. (2013). Examining the Professional Learning Community Practices:An Empirical Comparison from Malaysian Universities Clusters. Procedia - Social and Behavioral Sciences, 97, 105 - 113.

Louis, K.S., Marks, H.M., \& Kruse, S. (1996). Teachers' Professional Community in Restructuring Schools. American Educational Research Journal, 33(4), 757-798.

Marshall, M. (2007). Developing and Nurturing Professional Learning Communities: Principles Used By Elementary Administrators. (Unpublished master's thesis). Brock University, Toronto, Canada.

Marzano, R. (2003). What Works in Schools: Translating Research into Action. Alexandria, VA: Association for Supervision and Curriculum Development.

Marzano, R. J., Waters, T. and McNulty, B. A. (2005). School Leadership That Works: From Research To Results. Alexandria, VA: Association for Supervision and Curriculum Development (ASCD).

McLaughlin, M.W., \& Talbert, J.E. (2001). Professional Communities and the Work of High School Teaching. Chicago, IL: The University of Chicago Press.

McLaughlin, M., \& Talbert, J. (2006). Building School Based Teacher Learning Communities. New York, NY: Teacher College Press.

Ministry of Education. (2006). Malaysia Education Blueprint 2006-2010. Kuala Lumpur: Ministry of Education.

Ministry of Education. (2011). Strategic Plan Interim 2011. Kuala Lumpur: Ministry of Education.

Ministry of Education. (2012). Malaysia Education Development Plan. Kuala Lumpur: Ministry of Education.

Ministry of Education. (2013). Malaysia Education Blueprint Annual Report. Kuala Lumpur: Ministry of Education.

Morrissey, M. S. (2000). Comprehensive School Improvement: Addressing the Challenges. Issues about Change, 9(1)

Mostofo, J. (2013). Using Lesson Study with Pre-service Secondary Mathematics Teachers: Effects on Instruction, Planning, and Efficacy to Teach Mathematics. Doctorate Dissertation, Arizona State University.

Muhammad Faizal, A. G., Norfazira, M. R., Husaina, B. K., Saedah, S., Crow, G. C. and Faisol, E. (2013). Profesional Learning Community through the Islamic Perspective. Jurnal Hadhari, 5(2), 27-52.

Murphy, E. (1997). Characteristics of Constructivist Teaching and Learning. Constructivism: from Philosophy to Practice. http://www.cdli.ca/ elmurphy/emurphy/cle.html.

Myers, C., \& Simpson, D. (1998). Re-Creating Schools: Places Where Everyone Learns and Likes It. Thousand Oaks, CA: Corwin Press.

Parry, G. (2007). Improving Teacher Effectiveness through Structured Collaboration: A Case Study of a Professional Learning Community. Research in Middle Level Education Online, 31(1), 1-17.

Reichstetter, R. (2006). Defining a Professional Learning Community: A Literature Review. E\&R Research Alert Technical Report, No. 06.05.

Roberts, S., and Pruitt, E. (2009). Schools as Professional Learning Communities, Thousand Oaks, CA: Corwin Press.

Robson, C. (2002). Real World Research. A Resource for Social Scientists and Practitioner Researches (2nd edition.) Blackwell: Oxford.

Sekaran, U., \& Bougie, R. (2010). Research Methods. For Business: A Skill Building Approach (5th edition). West. Sussex, UK: John Wiley \& Sons Ltd.

Senge, P. (1990). The Leader's New World: Building Learning Retention. Educational Leadership, 47, 84-88.

Sigurðardóttir, A. K. (2010). Professional Learning Community in Relation To School Effectiveness. Scnadinavian Journal of Educational Research, 54(5), 395-412.

Spector, J. M., \& Davidsen, P. I. (2006). How Can Organizational Learning Be Modeled and Measured? Evaluation and Program Planning, 29(1), 63-69.

Stepanek, J., Appel, G., Leong, M., Mangan, M. T., and Mitchell, M. (2007). Leading Lesson Study: A Practical Guide for Teachers and Facilitators. Thousand Oaks: Corwin Press.

Stigler, J. W. \& Heibert, J. (1999). The Teaching Gap. New York, NY: The Free Press.

Stoll, L., MacBeath, J., Smith, I., \& Robertson, P. (2001). The Change Equation: Capacity for Improvement. In J. MacBeath \& P. Mortimore (Eds.), Improve the school effectiveness (169-190). Buckingham, UK: Open University Press.

Van Sickle, J. A. (2011). Lesson Study's Impact on Teacher Perception of Efficacy In Teaching. Master Thesis, Faculty of Humboldt State University.

Wells, G. (2001). The Case for Dialogic Inquiry. In G. Wells (Ed.), Action, talk, and text: Learning and teaching through inquiry (171-194). New York: Teachers College Press.

Yendol, D. (2010). Komuniti Pembelajaran Profesional. Buletin SIPartners. Retrieved from http://www.assafii.com/v2/index.php/en/pengurusankurikulum/pengurusan-panitia/196-komuniti-pembelajaran-profesional.

Zikmund, W.G., Babin, J., Carr, J. \& Griffin, M. (2012). Business Research Methods: with Qualtrics Printed Access Card. Cengage Learning.

Zuraidah Abdullah, Rahimah Ahmad, Muhammad Faizal Ab. Ghani \& Hailan Salamun. (2012). Komuniti Pembelajaran Profesional Dalam Kalangan Warga Sekolah Menengah Di Malaysia.IPBL. 